Historic, Archive Document

Do not assume content reflects current scientific knowledge, policies, or practices. 


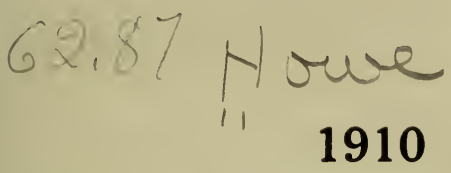

\section{THE NEW SEEDLING POTATO}

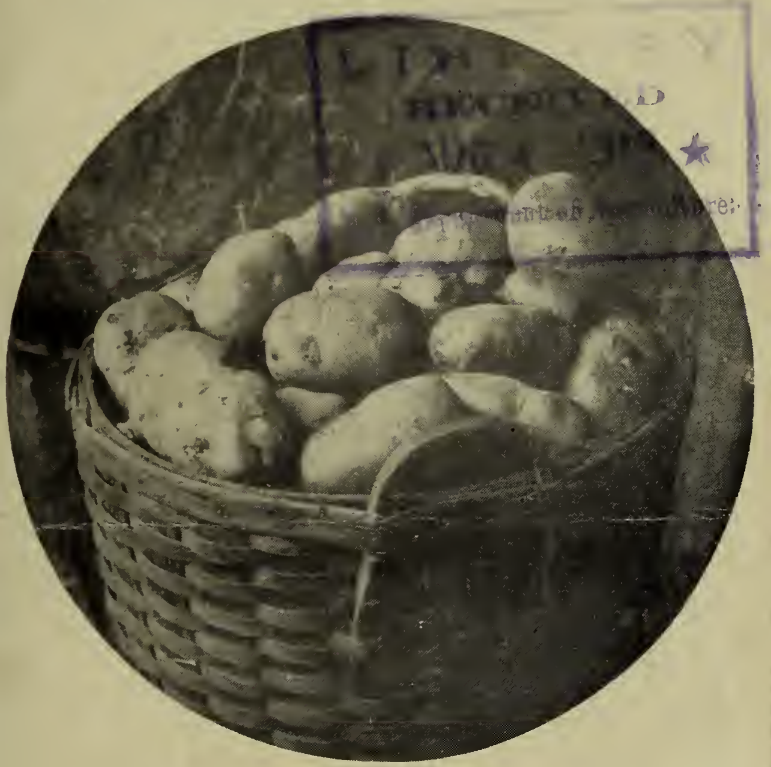

The above is a photograph of the wonderfully promising

\section{Seedling Potato}

Now offered to the public for the first time. Selections from this basket and other's from the same lot produced the crop now offered. The largest one in the picture was rejected, not planted. The size is somewhat exaggerated. 


\section{THE NEW KIND}

\section{\$}

This new potato was originated by $\mathrm{Mr}$. and Mrs. G. B. Johnson of Newfane village, Vt., who have had considerable experience in starting new varieties from the seed bulbs, selecting only those that appear, after repeated trials, to have better qualities than any of the old kinds.

These potatoes have been further developed by selections, and two years culture on the farm of M. O. Howe, Newfane, Vt. Their table qualities and other merits were thoroughly tested before deciding to introduce them as a new variety. We have no need of any more new kinds unless they are better, at least in some respects, than any of the old ones. It has been estimated that there are $50(10$ varieties of potatoes now in cultivation. Out of these it might, perhaps, be possible to select five that according to the purpose wanted-as early or late-would be better than any of the 
4995 others. It follows then that none of the 4995 varieties now in use are really worth cultivating because there is something better that might take their place.

\section{Get the Best Potato for Planting}

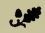 \\ The 1910 Seedling}

It is sold from first hands. No agents or dealers profits. The ordinary mailing price for which a new kind is sold by seedsmen and agents is $\$ 1.00$ per pound. This is too high. Yet I know several that have paid $\$ 1.00$ a pound for a new seedling, and have been great gainers by it. In one case, the products of the first pound was the largest lot of potatoes ever raised on one farm in Windham County, Vermontlast fall's crop.

Charles N. Codner of Owego, Tioga County, N. Y., an expert potato culturist and dealer, who advertised in The New York Tribune Farmer 70 different kinds of seed potatoes for sale, sent to me last spring for a few of my potatoes to test, writes: 
Mr. M. O. Howe, Newfane, Vt.

Dear Sir:-We are very much pleased with the seedling potatoes you sent us last spring. They had the most luxuriant vines all summer of any potatoes we had. They staid green until the frost killed them showing no disease. From the $10 \mathrm{lbs}$. you sent us we have dug something over $300 \mathrm{lbs}$. which we consider a good yield indeed.

\section{Very respectfully yours,}

Charles N. Codner.

11-8-09.

My own field, near Newfane village, had an exceedingly stout, vigorous growth of vines that continued to grow and remained a bright lively green until killed by frost, Oct. 13. I could append a large number of statements from neighbors, similar to the following from Rev. H. S. McHale of Brookline.

I was much impressed, as I passed by the farm of M. O. Howe last autumn, to note the magnificient growth and green appearance of his new variety of potatoes. They seemed exempt from blight and continued to grow far into October.

Rev. H. S. McHale.

Brookline, Vt. 
I do not warrant any potato as proof against disease. There is no man that is proof against it, and any potato grown in a soil that is full of disease germs will surely be affected. Rut one man may be less subject to disease than another. So may one potato, and that oNe is the oNE I now offer. 'The experiment stations are now seeking for the most disease resistant varieties.

\section{PREPAID MAIL PRICE}

\section{OF}

\section{THE 1910 SEEDLING}

One pound $20 \mathrm{cts}-3$ pounds $5 i$ ) cts. By express or freight, 1 peck $\$ 1.00-100$ pounds $\$ 2.50$ f. o. b.

\section{The Wardsboro Potato}

Also a new variety never before offered outside of the locality of its origin. One of the best medium early varieties known. Skin lightly shaded with brownish red. 
Highly recommended for excellent table qualities, sound tubers, and stout vines. By mail prepaid $15 \mathrm{cts}$ a pound-3 pounds 35 cts.

\section{The Planet}

This is one of the $\$ 1.00$ a pound potatoes to which reference has been made, and which last season produced the largest crop of potatoes in Windham county. It is a pure white, rather late potato, an enormous vielder, and one of the very best for a main crop. Instead of becoming poorer by keeping through the winter it is rather improved. It is a most excellent potato. Instead of $\$ 1.00$ a pound for which it was recently sold I can mail a pound, prepaid, for 15 cts. -3 lbs. for $35 \mathrm{cts}$. By express or freight f. o. b., 1 peck $50 \mathrm{cts}, 100 \mathrm{lbs}-\$ 1.50$.

\section{Get the Best}

Now is the time while potatoes are low to get stocked up with the very best. One or more of the five worth cultivation out of the 5000 varieties now in use because better than the other 4.995 . 
I can furnish selections from several of the best standard old varieties, as the Green Mountain, by mail prepaid, 1 lb. 10 cts., 3 lbs. 25 cts., by express or freight, 1 peck 30 cts., 100 pounds $\$ 1.50$ f. o. b.

\section{Potato Balls}

Containing the seeds from which new varieties are grown. In the balls or in packets, 100 to 200 seeds mailed for $10 \mathrm{cts}$. The old kinds do not now bear seed, and seedsmen do not generally advertise them because they cannot get them-a few offer them at 25 cts. a packet.

Address

\section{O. HOWE,}

\section{Newfane, VT.}

Terms in all cases, cash with order. 
